\title{
FROM FUNDAMENTAL FREEDOM TO POLITICAL AND ECONOMIC 'HOT POTATO' IN 50 YEARS: LABOUR MOBILITY AND MIGRATION WITHIN THE EU
}

\author{
John R. Dobson ${ }^{1} \&$ Irina Sennikova ${ }^{2}$ \\ Salford Business School, University of Salford, Salford, M5 4WT, England \\ E-mail: ${ }^{1}$ j.r.dobson@salford.ac.uk \\ Riga International School of Economics and Business Administration, Riga, Latvia \\ E-mail: ${ }^{2}$ irina@rsebaa.lv \\ Received 28 September 2006; accepted 24 January 2007
}

\begin{abstract}
The free movement of labour and the creation of a European Labour Market have been the objectives of the European Union since its creation, but it is only with the 2004 enlargement that this has started to become a reality, with substantial numbers of East European workers seeking employment in the old member states. This paper uses the data from the UK Worker Registration Scheme and that compiled by the European Commission to examine the nature of this movement and its impact on the economies of both the existing and the new member states.
\end{abstract}

Keywords: labour mobility, migration, the EU.

\section{Introduction}

On 1st May 2004, eight transitional states from Central and Eastern Europe (CEE) acceded to membership of the European Union (EU) expanding membership from 15 (EU-15) to $25^{1}$. The accession of the Czech Republic, Estonia, Hungary, Latvia, Lithuania, Poland, Slovakia and Slovenia (EU-8) was by far both the largest single expansion of the EU and since these states were the least economically developed ever admitted, the most diverse. With economic development much lower than that of existing members and expected to remain so for some time, this has raised many issues, which are making the expected accession of Bulgaria and Romania on $1^{\text {st }}$ January 2007 especially controversial. Many of these issues were discussed in a paper given to last year's conference (Dobson, 2006). This paper focuses on the effect of the 2004 accession on labour mobility and migration in the 'new Europe'. Some 50 years after it was first

1 Cyprus and Malta also joined in 2004. Bulgaria and Romania are expected to join on $1^{\text {st }}$ January 2007. Croatia and Turkey have also commenced discussions on membership. adopted as fundamental freedom by the 1957 Treaty of Rome, labour mobility and migration within the EU has become highly controversial and a major political and economic issue.

\section{EU Policy on the 'free movement of labour'}

The free movement of persons, that included the right to live and work in another member state is one of the fundamental freedoms guaranteed by the 1957 Treaty of Rome which created the $\mathrm{EU}^{2}$ (European Commission, 2002). A belief that the 'common market' involved the free movement of labour was one of the central tenants of the EU and one of the few areas of direct intervention in social policy included in the original 1957 Treaty of Rome, the other being equal pay. Implementing this has involved the mutual recognition of professional qualifications, the harmonisation of social security requirements, and discussion

\footnotetext{
${ }^{2}$ The current title European Union is used throughout, even when EEC or EC would be technically more accurate.
} 
of the need to create portable occupational pensions. More recently, the Lisbon European Council on 2324 March 2000 set an agenda of creating 'the most competitive and dynamic knowledge-based economy, sustainable economic growth with more and better jobs and greater social cohesion'. Creating a European labour market with inter-country labour mobility is seen as a way to achieve these objectives by combating skill and other labour shortages, reducing unemployment and offsetting the effects of a declining working age population (EC, 2000). The European Employment Services (EURES) was created to encourage the free movement of workers within the EU, and 2006 was declared the 'European Year of Workers' Mobility - Towards a European Labour Market' (Ingham and Ingham, 2006). However, it is far from clear that these laudable goals are shared by the populations of some Member States, especially after the 2004 enlargement.

\section{EU Policy on the 'free movement of labour after 2004}

The Accession Treaties introduced derogation from the principle of free movement of workers by allowing existing member states to introduce 'transitional measures' ${ }^{3}$ restricting access to their labour markets by workers from the new members for a maximum of seven years, with reviews required in 2006, 2009 and 2011 (the $2+3+2$ formula) ${ }^{4}$. In the event, only Ireland and Sweden and the UK granted workers from the EU-8 immediate access to their labour markets ${ }^{5}$. However the UK Government also put in place some transitional measures to monitor and restrict access to the UK labour market via the Worker Registration Scheme (WRS) which required EU-8 workers who

3 These transitional arrangements only applied to 'access' to the labour market. Once a worker obtained work, all other laws applied, including equal treatment as regards remuneration, social and tax advantages, and coordination of social security schemes.

4 Stage 1 ran from $1^{\text {st }}$ May 2004 until $30^{\text {th }}$ April 2006, Stage 2 from $1^{\text {st }}$ May 2006 until $30^{\text {th }}$ April 2009 and Stage 3 from $1^{\text {st }}$ May 2009 until $30^{\text {th }}$ April 2011. The expectation was that by the end of Stage 2 most restrictions would have been lifted. Countries were only allowed to retain restrictions if migration caused serious disturbances or some other labour market threat to domestic labour markets. Where an EU-15 country imposed restrictions, the EU-8 country was entitled to impose reciprocal restrictions and Hungary, Slovenia and Poland have done so.

5 Workers from Malta and Cyprus were given immediate rights to work throughout the EU, while Gibraltar imposed a work permit scheme, fearing the effect of immigration from Spain. wished to take up employment in the UK to register (registration was automatically granted in most cases) and denying access to welfare benefits including the use of state-run employment centres. All EU-8 countries granted workers immediate access to each others labour markets.

In May 2006, at the end of the first two-year transition period, a further 5 member states agreed to remove restrictions (Finland, Greece, Italy, Portugal, and Spain), with a further 5 agreeing to gradually lift restrictions during the 2nd three-year transition period ending in May 2009 (Belgium, Denmark, France, Luxembourg, and the Netherlands). The decision of France is particularly surprising given its $9,6 \%$ unemployment rate, which rises to $20 \%$ for those aged 18-25. Notwithstanding their concern for unemployment, France's social partners argued in favour of an immediate lifting of restrictions. Sectors which are short of labour (social and health care, hotels and catering, transport and construction) will be the first to open access to workers from EU-8. Austria and Germany are the only two countries to decide to keep restrictions in place until 2009, at which time they would be reviewed again. Germany is concerned about its own high unemployment rates, especially in the former East German federal states bordering the Czech Republic and Poland.

It is important to note that the adoption of transitional arrangements does not mean there is no immigration. Workers can continue to apply for employment via the traditional work permit route and can take up employment as a posted worker or as a self employed worker. Indeed, the transitional arrangements may have led to an exceptionally high influx of posted and self employed workers (European Commission, 2006: 5).

\section{Labour mobility before 2004}

Before 2004, the actual movement of labour within the EU was very limited, and most EU level discussion tended to complain about the absence of labour mobility. Only 4 per cent of EU citizens have ever lived in another EU State (Eurofound, 2006: 14) and in 2002 just 1.5 per cent of EU workers lived in a different member state, a figure which had remained unchanged for over 30 years (Recchi et al, 2002 cited in Ingham and Ingham, 2006: 677). Reasons often given for the failure of labour mobility are a lack of language skills, problems getting educational and professional qualifications recognised, and restrictive practices which exclude workers from other countries (Donaghey and Teague, 2006). 
The Erasmus student exchange programme and the proposed Services Directive are intended to go some way to resolve some of these problems. But there are many other practical, administrative and legal barriers which have prevented EU citizens from exercising their freedom of movement - social security and health care entitlements, entitlement to non-statutory pensions, unequal taxation, gaining recognition of qualifications and previous experience are all common problems. Language requirements based on 'mother tongue' are clearly discriminatory. To gain a residence permit, workers have been asked to provide excessive documentation other than that required by Community law. Public sector employment is a special case and is not covered by the free movement of workers, but the wide coverage of this exemption has raised particular and complex problems which led the European Court to restrict its coverage by making it 'post related' rather than 'sector related' and to apply only to those posts which 'exercise public authority' and have 'responsibility for safeguarding the general interests of the state'. Expulsion of those who become involuntarily unemployed is another problem area. Cross-frontier commuters face special problems. These problems are well documented in European Commission's 2002 Communication.

Historically, most international labour migration within the Community has been by relatively unqualified manual workers, not professionals. Language skills (or the lack of them) clearly inhibited the mobility of professional workers, whereas a supervisor or team leader, with some knowledge of the local language, is sufficient to meet the language requirements for unskilled workers (Grahl and Teague, 1992: 520; Marsden, 1994: 4). However the industrial crisis of the mid 1970s reduced the demand for unskilled foreign labour and movements of skilled and professional workers dominated these reduced flows. The general view on labour mobility was that 'We can conclude that there will be no major migration in the foreseeable future between EC countries' (Werner, 1994: 57). Grahl and Teague reached a similar conclusion 'With industrial slowdown and technical change in the northern European economies, the need for less qualified labour has fallen and the limited relations between labour markets in different EC countries have been weakened as a result'. With an EU-25 unemployment rate of $9 \%$, there is certainly no general shortage of labour (Ingham \& Ingham, 2004: 507). Marsden (1994) argued that 'their lower income levels suggest that the potential for migration may be greater from North Africa than from Eastern Europe'.

When Greece, Spain and Portugal joined in 1981 and
1986, there was concern that cheap labour would flood into the 'old' member states, owing to the difference in living standards and also the high unemployment rates in these countries. As a result transitional arrangements of six years were applied to these countries $^{6}$. But these fears were not born out and the migration flows remained negligible. Although the number of Greeks living in the rest of the EU increased by $30 \%$ during the ten years from 1987, this only resulted in an extra 102,000 migrants. The number of Portuguese living in the EU increased during the transition period but only by 30,000 (3\%), while the number of Spanish citizens actually decreased by 25,000 (5\%) (Dustmann et al, 2003: 44).

However there are differences between the Southern European states and the EU-8. Although the size of the economies of these Southern European States was about twice that of the EU-8, the relative difference in living standards was less. Greece, Spain and Portugal had in the GDP per head of $61 \%$ of the EC-9 in 1986 at PPP, compared with $45 \%$ of EU-15 average for the EU-8 in 2000 (Dustmann et al, 2003: 41). Also the market economy was much more developed in Greece, Spain and Portugal than in the EU-8. And although EU-8 has a much smaller percentage of its population employed in Agriculture (15\% compared with $26 \%$ ), output per unit of land and productivity are lower in the EU-8. All of these suggest that the experience of the accession of the Southern European States may not be replicated for the EU-8 enlargement which increased the EU population by $76 \mathrm{~m}(16 \%)$. The next two sections will examine the new 'push' and 'pull' factors which appear to have transformed migration patterns.

\section{Labour mobility after 2004}

When the British Government took the decision to allow workers from EU-8 to work in the UK, it estimated that no more than 5,000 to 13,000 workers per annum would move to Britain ${ }^{7}$ (Dustmann et al, $2003: 58)$. It is now clear that these predictions were

\footnotetext{
6 The transitional period of six years was applied to Greece and initially seven years for Spain and Portugal, although this was reduced to six when the expected influx did not materialise.

${ }^{7}$ These estimates were derived from some sophisticated statistical analysis of highly imperfect data. In the absence of migration figures, survey data was used and these produced small sample sizes especially from EU-8. The model contains assumptions for EU-8 based on historical figures from other countries. However the results were considered "not implausible in the light of past studies' (Dustmann et al, 2006:58).
} 
a massive underestimate. Equally wrong were the wild scare stories predicting an uncontrollable flood of 600,000 to 1 million migrants per annum (Migration Watch UK, 2003).

Prior to 2004, there were a number of indications that migration would take place. Illegal immigration was already a problem, especially into Germany from Hungary and Poland. Substantial numbers of Gypsies arrived at Dover, fleeing persecution in the Czech and Slovak Republics. French seamen took industrial action to protest against the employment of East European seamen at lower rates of pay. Germany opposed Turkey's EU membership because thousands of Turkish 'guest' workers would gain the right of permanent residence, with the prospect that thousands more would join them.

Although imperfect, analysis of UK Worker Registration Scheme (WRS) data provides some very interesting analysis of the EU-8 migration which has actually taken place into Britain (Great Britain, 2006). From $1^{\text {st }}$ May 2004 until 30 ${ }^{\text {th }}$ June 2006 some 447,000 workers applied to register with the WRS, with applications running at between 10,000 and 20,000 per month. Of these 17,000 applications were either rejected or withdrawn. Table 1 shows that the majority of applicants came from Poland (62\% of all applicants) followed by Lithuania (12\%), Slovakia (10\%), Latvia (6\%) and the Czech Republic (5\%). More men than women applied (58\% to $42 \%$ ). Table 2 shows that the majority of applicants were predominantly young ( $82 \%$ of applicants were between the ages of 18 and 34), and most did not have any dependents living with them in the UK. Even the

Table 1. Nationality of Applicants to UK Worker Registration Scheme ( $1^{\text {st }}$ May $2004-30^{\text {th }}$ June 2006)

\begin{tabular}{|l|l|l|}
\cline { 2 - 3 } \multicolumn{1}{c|}{} & Total & $\%$ \\
\hline Poland & 264,560 & 62 \\
\hline Lithuania & 50,535 & 12 \\
\hline Slovakia & 44,300 & 10 \\
\hline Latvia & 26,745 & 6 \\
\hline Czech Republic & 22,555 & 5 \\
\hline Hungary & 12,870 & 3 \\
\hline Estonia & 5,110 & 1 \\
\hline Slovenia & 420 & $<0,5$ \\
\hline Total & 427,095 & \multicolumn{2}{l}{}
\end{tabular}

Source: Great Britain (2006), page 9. Figures relate to approved applications and exclude multiple applications and re-registrations. figure of $7 \%$ with dependents may be an overstatement, because $47 \%$ of dependents were 17 and over, and many of these will be workers in their own right (Great Britain, 2006: 12). London and East Anglia were attractive locations accounting for $14 \%$ and $15 \%$ of registered workers respectively, but the percentage of applying for jobs in London is falling (Tables 1,2$)$.

Table 2. Age of registered workers on the UK Worker Register ( $1^{\text {st }}$ May $2004-30^{\text {th }}$ June 2006)

\begin{tabular}{|l|l|l|}
\hline Age & Number & $\%$ \\
\hline$<18$ & 1,235 & $<0.5$ \\
\hline $18-24$ & 183,250 & 43 \\
\hline $25-34$ & 167,635 & 39 \\
\hline $35-44$ & 44,710 & 10 \\
\hline $45-54$ & 26,130 & 6 \\
\hline $55-64$ & 3,400 & 1 \\
\hline $65+$ & 55 & $<0,5$ \\
\hline
\end{tabular}

Source: Great Britain (2006), page 11. Figures relate to registered workers rather than applications and exclude multiple applications and re-registrations.

It is important to understand the limitations of the WRS data, especially when using it as a basis for estimating the stock of EU-8 workers in the UK, because it both under-and over-estimates the true figures. Workers who are self-employed are not required to register (common in the construction industry), nor are 'posted workers' whose employer is based in an EU-8 country, but who is sub-contracted to work in the UK. This latter category is of particular concern because it may be used as a way of bypassing UK health and safety and employment legislation. Workers are required to register for each job and every time they change employers, although the figure of 447,000 excludes 133,000 multiple applications and re-registrations (Tables 3, 4, 5). There are claims that many workers have obtained work without registration, although how many is difficult, if not impossible, to estimate. A number of young Polish workers were interviewed who had not registered because of ignorance about the scheme or because of the cost (£70). One was working for a national restaurant chain without a national insurance number and another had no difficulty in obtaining a national insurance number without registering.

The number of registrations overstates the number of EU-8 workers residing in the UK, because it only records inflows and no record is kept of those leav- 
Table 3. Main Occupational groups of registered workers on the UK Worker Register ( $1^{\text {st }}$ May $2004-30^{\text {th }}$ June 2006)

\begin{tabular}{|l|c|c|c}
\hline & Q2, 2004 & Q2, 2006 & 2004-6 \\
\cline { 2 - 4 } & $\%$ & $\%$ & $\%$ \\
\hline $\begin{array}{l}\text { Administration, } \\
\text { Business } \\
\text { and Management }\end{array}$ & 17 & 39 & 34 \\
\hline $\begin{array}{l}\text { Hospitality and } \\
\text { Catering }\end{array}$ & 31 & 18 & 21 \\
\hline Agriculture & 21 & 14 & 12 \\
\hline Manufacturing & 6 & 6 & 7 \\
\hline $\begin{array}{l}\text { Food, Fish and } \\
\text { Meat processing }\end{array}$ & 4 & 4 & 5 \\
\hline
\end{tabular}

Source: Great Britain (2006), page $13 \& 14$. Figures relate to registered workers rather than applications and exclude multiple applications and re-registrations.

Table 4. Top Occupations of registered workers on the UK Worker Register ( $1^{\text {st }}$ July $2004-30^{\text {th }}$ June 2006)

\begin{tabular}{|l|l|}
\hline & $\%$ \\
\hline Process operatives (\& other factory workers) & 37 \\
\hline Warehouse & 10 \\
\hline Packer & 10 \\
\hline Kitchen and catering asst & 9 \\
\hline Cleaners/domestic staff & 8 \\
\hline Farm worker & 7 \\
\hline Waiter/waitress & 6 \\
\hline Maid/room attendant Hotel & 5 \\
\hline Care assistants/home carers & 5 \\
\hline
\end{tabular}

Source: Great Britain (2006), page 15. Figures relate to registered workers rather than applications and exclude multiple applications and re-registrations.

ing the UK. Many workers only come for short-term or seasonal work, especially in agriculture and hospitality. The data may also over-estimate post-2004 migration because some of the registrations are previously illegal immigrants regularising their employment status.

It is also important to place these migration figures in a wider context. Firstly, migration is not just the result of the decision by the UK Government to allow EU-8 immigration in 2004. It is perfectly possible that many of these workers would have come to the UK anyway and could have legally obtained work via the work permit scheme, as many workers from outside the EU continue to do - 137,000 workers and their dependents entering the UK from outside the EU in 2005 (Home Office, August 2006). Sec-
Table 5. Numbers of workers employed in selected occupations

\begin{tabular}{|l|l|}
\hline Process operative & 99,715 \\
\hline Warehouse operative & 25,215 \\
\hline Packer & 24,130 \\
\hline Kitchen and catering assistant & 24,090 \\
\hline Cleaners/domestic staff & 20,430 \\
\hline Farm Worker & 18,105 \\
\hline Waiter/waitress & 15,840 \\
\hline Maid & 13,835 \\
\hline Care assistants and home carers & 12,610 \\
\hline Food processing operative & 11,325 \\
\hline Sales and retail assistants & 10,535 \\
\hline Labourer Building & 10,525 \\
\hline Crop Harvester & 8,020 \\
\hline Bar staff & 6,030 \\
\hline Driver, HGV & 3,620 \\
\hline Fruit pickers & 3,580 \\
\hline Driver, delivery van & 2,695 \\
\hline Hotel Porter & 2,435 \\
\hline Driver, bus driver & 2,245 \\
\hline Hotel receptionist & 1,230 \\
\hline Security guard & 1,205 \\
\hline Driver, bus & 665 \\
\hline Doctors & 490 \\
\hline Dentists & 310 \\
\hline Teachers - schools & 215 \\
\hline Teachers - higher education & 140 \\
\hline
\end{tabular}

Source: Great Britain (2006), Annex A.

ondly, these workers may be temporary rather than permanent additions to the UK workforce. A survey reported in the Guardian (2006) indicate that the majority of EU-8 workers say that they want to leave - 193,000 within 2 years and 54,000 within 3 to 4 years, which confirms the stated intentions in an earlier survey by the International Organisation for Migration (Dustman et al, 2003: 35). This is consistent with the 2005 figures which show that 80,000 EU-8 citizens arrived in the UK, but only 16,000 left, because these are for the first full year of unrestricted migration and therefore do not represent a steady state position. Thirdly, migration is not a one way process, and emigration has been rising steadily particularly with increasing numbers of retired people choosing to live abroad. Figures from the International 
Passenger Survey suggest that by 2005, this exodus had risen to 380,000 , but only in the last 10 years has net migration become positive with a total net UK migration of 185,000 in 2005. Also, some sense of perspective is required because this survey also suggests that in 2005 migration from the EU-8 $(80,000)$ is dwarfed by migration from the Commonwealth $(189,000)$, other foreign nationals $(140,000)$ (National Statistics News Release, $2^{\text {nd }}$ November 2006). Table 8 shows that except for Luxemburg and Belgium, all other EU-15 countries also have substantially larger non-EU immigrant populations.

A second important source of comparative data is the European Commission Report (European Commission, 2006), whose figures shown in Table 6 are derived from both administrative data provided by the Member States and also from labour force surveys (LFS). While LFS data may be a more accurate indicator of

Table 6. EU-10 nationals as a percentage of EU-15 working age population (15-64 years)

\begin{tabular}{|c|c|c|c|}
\hline \multirow{2}{*}{ EU-15 } & $\begin{array}{l}\text { Administrative } \\
\text { data, } 2004\end{array}$ & LFS, 2003 & $\begin{array}{l}\text { LFS, } \\
2005\end{array}$ \\
\hline & $\%$ & $\%$ & $\%$ \\
\hline Ireland & 1,9 & --- & 2 \\
\hline Austria & 1,2 & 0,7 & 1,4 \\
\hline Germany & 0,9 & --- & 0,7 \\
\hline UK & 0,4 & 0,2 & 0,4 \\
\hline Belgium & 0,2 & 0,2 & 0,2 \\
\hline Netherlands & 0,2 & 0,1 & 0,1 \\
\hline Denmark & 0,1 & --- & --- \\
\hline Greece & 0,1 & 0,3 & 0,4 \\
\hline Italy & 0,1 & --- & --- \\
\hline Sweden & 0,1 & 0,2 & 0,2 \\
\hline Finland & 0 & 0,3 & 0,3 \\
\hline Spain & 0 & 0,2 & 0,2 \\
\hline France & 0 & 0,1 & 0,1 \\
\hline Portugal & 0 & --- & --- \\
\hline Luxemburg & & 0,3 & 0,3 \\
\hline average & & 0,2 & 0,4 \\
\hline
\end{tabular}

Note 1: administrative data is derived from Member states and the figures may not be comparable. For example, Ireland's figures are based on the issue of Personal and Public Service Numbers which over estimates the number of workers because not only workers are issued with these numbers. UK data is derived from the WRS. Other countries use work or residence permits.

Note 2: LFS figures include inflows and outflows and so ought to be more reliable.

Source: European Commission, 2006:8\&9. the number of EU-8 workers than residence and work permit statistics because they make allowance for outflows as well as inflows, there are problems associated with small sample sizes for EU workers and also they probably underestimate the number of EU8 workers because many live in communal establishments (Gilpin, 2006: 11).

Ireland comes top with almost $2 \%$ of its working age population coming from EU-10. Next comes Austria with in excess of $1 \%$, which is interesting given the expectation that it will maintain its transitional arrangements for the maximum period. Germany follows with less than $1 \%$. The UK and Greece trail in joint fourth position with about $0,4 \%$ of their working age populations coming from the EU-10. Interestingly, there is no evidence from either administrative source or LFS data, that transitional arrangements had much effect on mobility. As is shown in Tables $7 \& 8$, most countries have substantially more of their immigrant population coming from the EU15 than the EU-10, with Belgium and Luxemburg having exceptionally high numbers as home of the European Commission and Parliament. Even Ireland has over $50 \%$ more of its working age immigrant population coming from the EU-15 than the EU-10, and the United Kingdom over three times the number with $1.7 \%$ of its working age population coming from

Table 7. Other EU-15 nationals as a percentage of EU-15 working age population (15-64 years)

\begin{tabular}{|l|c|c|}
\hline \multirow{2}{*}{ EU-15 } & LFS, 2003 & LFS, 2005 \\
\cline { 2 - 3 } Luxemburg & $\%$ & $\%$ \\
\hline Belgium & 37,2 & 37,6 \\
\hline Ireland & 5,4 & 5,8 \\
\hline Germany & 3,4 & 3 \\
\hline Sweden & 2,7 & 2,8 \\
\hline France & 2,2 & 2,3 \\
\hline UK & 1,9 & 1,9 \\
\hline Austria & 1,8 & 1,7 \\
\hline Netherlands & 1,7 & 1,9 \\
\hline Spain & 1,5 & 1,4 \\
\hline Denmark & 1,1 & 1,2 \\
\hline Finland & 1 & 1,1 \\
\hline Portugal & 0,3 & 0,4 \\
\hline Greece & 0,3 & 0,4 \\
\hline Italy & 0,2 & 0,3 \\
\hline
\end{tabular}

Source: European Commission, 2006:8\&9. 
Table 8. Resident working population by nationality (\%) 2005

\begin{tabular}{|l|c|c|c|c|}
\hline & National & EU-15 & EU-10 & non-EU \\
\hline Belgium & 91,3 & 5,8 & 0,2 & 2,8 \\
\hline Denmark & 96,4 & 1,1 & & 2,4 \\
\hline Germany & 89,5 & 2,8 & 0,7 & 7 \\
\hline Greece & 94 & 0,3 & 0,4 & 5,3 \\
\hline Spain & 90,5 & 1,2 & 0,2 & 8,1 \\
\hline France & 94,4 & 1,9 & 0,1 & 3,6 \\
\hline Ireland & 92,3 & 3 & 2 & 2,8 \\
\hline Luxembourg & 57,9 & 37,6 & 0,3 & 4,2 \\
\hline Netherlands & 95,7 & 1,4 & 0,1 & 2,8 \\
\hline Austria & 89,2 & 1,9 & 1,4 & 7,5 \\
\hline Portugal & 97 & 0,4 & & 2,6 \\
\hline Finland & 98,3 & 0,4 & 0,3 & 1 \\
\hline Sweden & 94,8 & 2,3 & 0,2 & 2,7 \\
\hline United Kingdom & 93,8 & 1,7 & 0,4 & 4,1 \\
\hline
\end{tabular}

Source: European Commission, 2006, Table A 2, p.17

other EU-15 countries compared with $0,4 \%$ from the EU-10 in 2005. Sweden had 2,3\% from EU-15 compared with $0,2 \%$ from EU-10. And immigration from non-EU countries is even more important than intraEU mobility. One must wonder from these figures whether the political and media attention that CEE migration has received is justified.

It should also be born in mind that many of the residence/work permits are granted for short-term or seasonal workers. Most work permits granted by Austria were for less than six months $(85 \%$ in the first half of 2005), and a smaller percentage (14\% in 2005) for 6-12 months. In Germany, $95 \%$ of the work permits are issued with time restrictions. In Italy, $71 \%$ of work authorisations were for seasonal workers, and $74 \%$ in France (European Commission, 2006:10).

Mobility flows from EU-15 to EU-10 and between EU-10 are negligible (CEC 2006 table A1). The Czech Republic is the only EU-8 country to have received hardly any immigration from other EU-10 countries $1,0 \%$ of working age population.

\section{EU-8 migration to EU-15 - theoretical explanations}

Migration can be explained by push factors causing workers to leave their home country but by itself this is not enough, there must also be pull factors in the
Table 9. Unemployment Rates 2003

\begin{tabular}{|c|c|}
\hline & $\%$ \\
\hline \multicolumn{2}{|l|}{ EU-15 } \\
\hline Austria & 4,4 \\
\hline Belgium & 8,1 \\
\hline Denmark & 5,6 \\
\hline France & 9,4 \\
\hline Finland & 9 \\
\hline Germany (west and east) & 9,3 \\
\hline Greece & 9,3 \\
\hline Italy & 8,6 \\
\hline Luxembourg & 3,7 \\
\hline Netherlands & 3,8 \\
\hline Portugal & 6,4 \\
\hline Spain & 11,3 \\
\hline Sweden & 5,6 \\
\hline UK & 5 \\
\hline Ireland & 4,6 \\
\hline \multicolumn{2}{|l|}{ EU-10 } \\
\hline Cyprus & 4,4 \\
\hline Czech Republic & 7,8 \\
\hline Estonia & 10,1 \\
\hline Hungary & 5,8 \\
\hline Latvia & 10,5 \\
\hline Lithuania & 12,7 \\
\hline Malta & 8,2 \\
\hline Poland & 19,2 \\
\hline Slovakia & 17,1 \\
\hline Slovenia & 6,5 \\
\hline \multicolumn{2}{|l|}{ Prospective members } \\
\hline Bulgaria & 13,6 \\
\hline Romania & 6,6 \\
\hline Turkey & 9 \\
\hline
\end{tabular}

Source: United Nations Economic Commission for Europe, The Statistical Yearbook, 2005

form of an attractive new country willing to accept them and employers prepared to offer employment. In the absence of legal restrictions on migration, basic economic theory would predict substantial population movements from the low wage new member states which will in turn exert a downward pressure on 
wages. Individual workers will seek to maximise their utility and if wages and working conditions are better in the EU-15, seek employment there. Interestingly, workers cited better living conditions abroad as more important than higher wages as a reason for migra-

Table 10. Percentage of people who expect to move to another EU country within 5 years by age and educational level

\begin{tabular}{|l|l|l|}
\hline Age & $\begin{array}{c}\text { Czech Republic, } \\
\text { Hungary, Slovenia, } \\
\text { Slovakia }\end{array}$ & $\begin{array}{c}\text { Baltic States + } \\
\text { Poland }\end{array}$ \\
\hline $18-24$ & 38 & 35 \\
\hline $25-34$ & 33 & 40 \\
\hline $35-44$ & 13 & 17 \\
\hline $45-54$ & 3 & 6 \\
\hline $55-64$ & 6 & 1 \\
\hline $65+$ & 7 & 0 \\
\hline & & \\
\hline Educational Level & 3 \\
\hline Low & 6 & 32 \\
\hline Average & 46 & 32 \\
\hline High & 24 & 34 \\
\hline $\begin{array}{l}\text { still } \\
\text { studying }\end{array}$ & 24 & 0 \\
\hline
\end{tabular}

Source: Foundation for the Improvement of Living and Working Conditions 'Mobility in Europe - Analysis of the 2005 Eurobarometer survey on geographical and labour market mobility' Table 4. tion (Dustmann et al, 2003: 38). This is the approach argued by the European Commission:

'ultimately, mobility flows are driven by factors related to supply and demand conditions. If anything, TA [transitional arrangements] will only delay labour market adjustments, with the risk of creating "biased" destination patterns. Restrictions on labour market access may exacerbate resort to undeclared work' (European Commission, 2006: 11).

However notions of individual utility maximisation may be somewhat artificial in practice and migration decisions may represent collective utility maximisation by the family or household, with a family member working abroad to support the family, and may involve Grandparents or other relatives volunteering for child rearing duties.

It is quite clear that wages and working conditions are better in the EU-15 than the EU-8. In 2004, the EU-8 had the GDP per head of only $45 \%$ of the average for the EU-15. Only three of the new members had the GDP per head above half that of the EU15 average (Slovenia, $70 \%$ and Czech Republic $63 \%$, Hungary $55 \%$ ). Latvia and Lithuania had the lowest of $37 \%$ and $41 \%$ respectively. These are quite important pull factors, if work is available, and this latter qualification is a very important caveat. Analysis of the figures contained in Table 11 show that $70 \%$ of the variation in migration by nationality can be explained by size of population and GDP (Gilpin et al, 2006).

Table 11. Applicants to UK Worker Registration Scheme (1 $1^{\text {st }}$ May $2004-30^{\text {th }}$ June 2006), population, 2004, GDP per head, 2004 and Unemployment rate, 2005

\begin{tabular}{|c|c|c|c|c|c|c|}
\hline & Applicants & $\%$ & Population & $\%$ & GDP per head & \\
\hline & to WRS & & (millions) & & EU-25=100, & $\%$ \\
\hline Poland & 264,560 & 62 & 38.2 & 10 & 47 & 17.9 \\
\hline Lithuania & 50,535 & 12 & 3.4 & 0.9 & 48 & 8.2 \\
\hline Slovakia & 44,300 & 10 & 5.4 & 1.4 & 52 & 16.4 \\
\hline Latvia & 26,745 & 6 & 2.3 & $<0.5$ & 43 & 9 \\
\hline Czech Republic & 22,555 & 5 & 10.2 & 2.7 & 70 & 8 \\
\hline Hungary & 12,870 & 3 & 10 & 2.6 & 61 & 7.1 \\
\hline Estonia & 5,110 & 1 & 1.3 & $<0.5$ & 51 & 7.5 \\
\hline Slovenia & 420 & $<0.5$ & 2 & 5.2 & 79 & 5.8 \\
\hline Total & 427,095 & & 383.5 & & & \\
\hline
\end{tabular}

Source: Great Britain (2006), page 9. figures relate to applications approved and exclude multiple applications and re-registrations (K. Barysch, 2006:Table 1\&2). 
Further, there are also some very strong push factors. Although most CEE countries have recovered from the catastrophic economic collapse of the early 1990s, as shown in Table 9, unemployment is still high with substantial long-term unemployment and regional disparities. The average unemployment rate in 2004 was over $11 \%$ for the EU-8 compared with $8 \%$ for the EU-15. But these average figures reveal some stark variations. Poland and Slovakia have the highest unemployment rates of $19 \%$ and $18 \%$ respectively, whereas Hungary has the lowest of $6 \%$. In both Poland and Slovakia, the unemployment rate for young people is much higher at $40 \%$ and $33 \%$ respectively for 15-24 year olds. Eligibility for unemployment support is often highly restricted. There is widespread employment and social discrimination against ethnic minorities in some countries (Dobson and Jones, 1998; Dobson, 2001). Traditional systems of social protection are woefully inadequate with minimum wages below the level necessary to support a single person (Standing 1997: 155).

However migration theory and practice is extremely complicated. Comparing actual migration levels with the differences in wage and unemployment levels between EU-8 and EU-15, it is difficult not to conclude that the wrong question is being asked. The question should not be 'why so many workers from CEE have moved west', but 'why so few'? However, the link between poverty and likelihood to travel in search of work is tenuous. One look at the country of origin demonstrates greatest mobility has not been from the poorest EU-8 countries, and it is not the poorest people within those countries who have migrated. There are a number of reasons why tra-

Table 12. WRS Applications May 2004 - Sept 2005 as a \% of 2005 population GDP per head in 2005

\begin{tabular}{|l|c|c|}
\hline & $\begin{array}{c}\text { WRS applications } \\
\text { as \% of home } \\
\text { population }\end{array}$ & $\begin{array}{c}\text { GDP per head in } \\
\text { 2005 } \\
\text { Euros at } 1995\end{array}$ \\
\hline Lithuania & 1,16 & 2,500 \\
\hline Latvia & 0,86 & 3,100 \\
\hline Slovakia & 0,57 & 4,200 \\
\hline Poland & 0,44 & 4,200 \\
\hline Estonia & 0,3 & 4,000 \\
\hline $\begin{array}{l}\text { Czech } \\
\text { Republic }\end{array}$ & 0,17 & 5,200 \\
\hline Hungary & 0,08 & 5,000 \\
\hline Slovenia & 0,01 & 11,400 \\
\hline
\end{tabular}

Source: Gilpin et al, 2006:15. ditional economic theory has only limited predictive ability. Language skills and financial resources are important pre-requisites for successful migration. Some CEE workers who have arrived in Britain without a job, without language skills, and with little money have had a very hard time indeed, ending up living on the streets especially in London, dependant on charity-run soup kitchens for food and unable to return home.

Process itself is an extremely important explanation of migration flows. How do CEE workers actually find jobs and accommodation in Western Europe? Personal and Family networks are important facilitators of mobility, which minimise risk. Diaspora communities can provide accommodation, aid with job search and provide 'insider' support into how processes work. A substantial Polish community was established in Britain following the $2^{\text {nd }}$ World War and this perhaps explains why Polish workers have a substantial advantage in the post 2004 migration flows. Polish Churches and social clubs in Britain function as labour exchanges and advice centres. In the words of one interviewee 'people in the Polish Church know what forms are required and how to fill them in far better than the staff in the British Govt offices'. When asked how she had found work in a hotel complex in a remote rural area, one young waitress replied that 'my cousin worked here and got me the job'. Another cited 'help from a boyfriend'. Also important in facilitating migration is the existence of international recruitment agencies, and employment web-sites. But an important determinant of migration is whether West European employers will be attracted to use much cheaper European labour and if so, under what conditions? This is considered in the next section.

\section{Effects of labour mobility on the EU 15}

Two conflicting arguments are being raised about the effect of EU-8 migration on EU-15 economies. On the one hand it is argued that migration has an important positive effect on EU-15 economies because it alleviates labour shortages and skill bottlenecks, thereby increasing growth, reducing inflation, and also interest rates. Migration is very important because it offsets the effects of the so-called 'demographic time bomb' affecting western labour markets, of a declining working population caused by falling birth rates leading to an aging population. Replacing an economically inactive population who are retiring to warmer climates, with economically active younger workers from Eastern Europe can seem like very good economic news indeed, not just because they increase 
output, but also because they increase the pool of tax payers.

The opposite argument is that EU-8 migration is exerting a downward pressure on wages and social standards causing a 'race to the bottom'. In this race, national workers are being 'crowded out' of the labour market, either because cheaper EU-8 workers are being used as a direct replacement for more expensive existing national workers, or because they are taking jobs which would otherwise have gone to the jobless. The rise in immigration is also exacerbating housing shortages, and putting a severe strain on transport, the welfare system, schools and hospitals. One consequence of this is a rise in ethnic and social tensions which has serious implications for society.

In September 2005, all three countries which adopted an open door policy after accession (UK, Sweden and Ireland) reported positively about effects of migration on their economies (European Commission, 2006: 5), though the basis for this assessment is far from clear. Assessing the impact of EU-8 migration on the economy is far from straightforward, and it is difficult to isolate the effect of enlargement because immigration was taking place before 2004 and may have increased anyway. However, for the first time we now have some empirical evidence which can be used to tentatively assess these arguments. Are EU15 employers using CEE labour simply to meet labour and skill shortages, or are they using CEE labour to displace more expensive indigenous workers?

Looking at the migration patterns to date, it is clear that there are no global answers to these questions. Certainly a number of high profile strikes have suggested that some employers have used cheap CEE labour to displace indigenous workers - the Irish Ferries dispute in 2004, Viking Ferries dispute on the Helsinki to Tallinn route in 2004, and the Vaxholm (Sweden) construction industry dispute in 2004, (Donaghey and Teague, 2006; Woolfson and Sommers, 2006). However, these employers may not be typical. The shipping industry has been subject to strong competitive pressures for a number of years and 'flagging-out' disputes pre-date the 2004 Accession.

Data on the industrial and occupational destinations of CEE migrants from the WRS provides some evidence of the motivations of British employers, and the effect on the economy. It is clear from Tables 3 \& 4 that most EU-8 workers work full-time in low skilled jobs. The largest occupational group is 'Administration, Business and Management' (34\%) which has grown substantially over the period, but since most of these workers are 'temps' working for recruitment agencies, it is unlikely that they are working in high skilled occupations. The next two biggest occupational groups are 'hospitality and catering' $(21 \%)$ and 'agriculture' $(12 \%)$ but these have fallen. Work in these latter groups is highly seasonal; therefore many of these workers may work for a short time before returning home. Forty four percent of workers in London are in Hospitality and Catering. Looking at the occupations of EU-8 workers shown in Table 5, one cannot fail to be struck by the overwhelming low skill/ low paid nature of their occupations, 25,000 work as warehouse labourers, 24,000 work as kitchen/catering assistants, 24,000 as factory packers, 20,500 as cleaners, 18,000 as farm hands, 14,000 as maids and 12,700 as care workers and 6,500 as bus, lorry and coach drivers. The vast majority (78\%) of WRS workers are working at or near the national minimum wage earning between $£ 4-50$ and $£ 5.99$ per hour. By comparison, the numbers working in high skilled occupations are very low, 310 dentists, 490 doctors, 140 University lecturers, 215 school teachers.

The above figures reveal some disturbing features about the malfunctioning of the British labour market. Contrary to the popular argument, EU-8 immigration is not substantially combating the longstanding skill shortage problem. Instead, British employers are using CEE labour to fill shortages in low paid and unskilled labour. With unemployment rising to 5,6\% overall, and at $11 \%$ for 16-24 year-olds, rising to over $25 \%$ for 16 and 17 year-olds, the UK labour market is clearly not functioning. There is a problem of geographical mobility and/or work attitudes and capability of British youth.

Comparing the educational composition of EU-8 workers in the UK with that of the national workers, reveals that they have less with low educational level attainment than nationals $(21 \%$ as against $31 \%$ for nationals), a greater proportion with medium educational level (57\% as against $46 \%$ for nationals) and roughly the same for higher educational level (CEC 2006:13) (Table 6). The 2005 Eurobarometer survey' also found that those with a higher educational level were twice as likely to move within the EU (Eurofound, 2006: table 1). This may have important consequences for assessing their impact on the UK economy. Eurofound thought that this reflected the demand for highly skilled professionals which had created an international labour market, but as argued above, this does not appear to be the case. Given that the majority are working in low skilled jobs, they are likely to be over-skilled for the jobs they do. But this may be the reason why many employers have expressed a preference for EU-8 workers, commenting 
on their greater efficiency, positive attitude and lower absenteeism. One car parts manufacturer near Rhyl was quoted as saying that EU-8 workers were 'hardworking, reliable and motivated' that their 'attendance was really good' and that they 'helped stabilise the workforce, reduce absenteeism, and increased productivity' (Observer, 27th Aug 2006). This employer also commented adversely on their English skills, but noted how quickly it improved once evening English classes were arranged. On the one hand a lack of language skills may be why many workers are working below their educational level, but may also explain why they are displacing low paid British workers.

Another important consideration in assessing the impact of EU-8 workers on the EU-15 economies will depend on whether workers from the EU-8 are permanent workers, like the mass migrations from Asia and Africa which took place during the 1960s and 1970 s, or are they temporary workers, more akin to the 'guest-workers' in Germany? To date there are a number of reasons to believe that the majority of EU-8 workers are likely to be temporary workers who will return home after a short spell of working in the UK. Firstly the majority are young workers with no permanent ties to the UK. Secondly, the vast majority are in temporary or low skilled jobs. WRS data indicates that $49 \%$ of EU-8 workers are in temporary jobs, rising to $69 \%$ and $82 \%$ respectively in agriculture and administration/business sectors. But this figure probably understates the extent of temporary jobs because $80 \%$ of workers in hospitality and catering are permanent. Given traditional rates of labour turnover in these industries, the notion of a permanent job may be theoretical rather than real. One young female graduate interviewed cited 'no career prospects, boring work, and inability to afford higher education' as reasons why she had given up her job stacking shelves in a supermarket in Ireland in order to return home and take a low paid clerical job which allowed her to study for an MBA. And thirdly, given the low pay, there is no prospect that these young people could obtain family accommodation, especially in the South East (Hardy and Clark, 2005: 6).

It has been argued that EU-8 immigration has placed 'enormous pressure on education, health, welfare services' in a leaked UK Government Report (Guardian $31^{\text {st }}$ July 2006). But WRS data shows that the majority of EU-8 workers are young, relatively well educated, have no dependents with them in the UK, and make few demands on the welfare system, and so it is difficult to see how these claims can be reconciled with the nature of the workforce. This is not to say that there are no problems. An educational manager organising 'special needs' education in one large city, noted that 'we were getting so many CEE children who cannot speak English, we are having to establish special classes'.

When the European Commission tested the 'crowding out thesis' by comparing the composition of the workforce by sector, across all EU-15 countries, they found that in only two sectors, - 'construction' and 'retail, hotels/restaurants; transport' did EU 10 workers have a higher employment rate than nationals (CEC, 2006: 12). Indeed, only in agriculture and manufacturing is the proportion of EU-8 workers significant ( $7 \%$ and $2 \frac{1 / 2}{\%}$ respectively (Gilpin et al, 2006: 20 21) (Table 12). However this sector by sector analysis may not be the appropriate methodology, especially for largely unskilled workers. Only if we take as given that the indigenous unemployed lack geographical mobility, lack in occupational flexibility and reluctance to work in certain sectors, there is no 'crowding out' of British workers and therefore EU8 migration has probably increased British growth rates. While depressing, this assumption may be realistic. The other problem with the crowding out thesis is whether we are comparing 'like with like'. If EU-8 workers are more productive because they have a positive work ethic compared with 'home grown youth', then there has possibly been some crowding out of the less educated, less productive, who have been driven out of the labour market because they are not very competitive, and this may have resulted in increased unemployment and at the same

Table 13. Foreign languages percentage who speak

\begin{tabular}{|l|c|c|c|c|c|c|}
\hline \multirow{2}{*}{} & \multicolumn{2}{|c|}{ English } & \multicolumn{2}{c|}{ German } & \multicolumn{2}{c|}{ Russian } \\
\cline { 2 - 7 } & $\begin{array}{c}\text { (i) } \\
\%\end{array}$ & $\begin{array}{c}\text { (ii) } \\
\%\end{array}$ & $\begin{array}{c}\text { (i) } \\
\%\end{array}$ & $\begin{array}{c}\text { (ii) } \\
\%\end{array}$ & $\begin{array}{c}\text { (i) } \\
\%\end{array}$ & $\begin{array}{c}\text { (ii) } \\
\%\end{array}$ \\
\hline Czech Republic & 24 & 64 & 27 & 49 & 21 & 0.5 \\
\hline Estonia & 29 & 86 & 13 & 36 & 53 & 54 \\
\hline Hungary & 14 & 63 & 13 & 60 & 2 & 1 \\
\hline Latvia & 23 & 88 & 14 & 33 & 59 & 39 \\
\hline Lithuania & 20 & 73 & 13 & 34 & 83 & 59 \\
\hline Poland & 21 & 80 & 16 & 53 & 28 & 18 \\
\hline Slovakia & 13 & 56 & 20 & 51 & 30 & 7 \\
\hline Slovenia & 46 & 85 & 38 & 30 & 2 & 0 \\
\hline
\end{tabular}

Column (i) percentage of population who spoke well enough to take part in a conversation

Column (ii) percentage of secondary school pupils who are learning language

Note : population speaking French, Spanish and Italian are very small.

Source:Dustmann et al, 2003: Tables 3.5 \& 3.6, p 25-26. 
time increased growth rates. Also, older national workers trying to get back into the labour market following redundancy may also be being crowded out. There is some evidence for this because non-migrants appear to bear the cost of economic slowdown disproportionately more than migrants (Gilpin et al, 2006: 8). In 2005 the fall in recruitment was $13 \%$ for nonmigrants and only $7 \%$ for migrants, moves from nonwork to work declined by $10.5 \%$ amongst non-migrants and only by $2.5 \%$ amongst migrants.

Has EU-8 migration depressed wages and reduced inflation? Most of the occupations taken up by the EU-8 are currently at or near the national minimum wage, so it is therefore difficult to see how they can have pushed down the wages of UK workers. However, they may have prevented wages from rising if employers would have had to increase wage rates to fill these posts. If this is true, then EU-8 workers may have directly reduced inflation. Given that EU-8 workers are concentrated in a limited number of low paid occupations, most British workers continue to be insulated from direct and immediate competition with the unemployed and disadvantaged workers of Eastern Europe, and may have benefited from lower prices (Grahl and Teague, 1992). But when many prices rise and fall, it seems rather unsatisfactory to blame a wage rise for the poorest workers for increased inflation. Also, it cannot be assumed that the profitability of many of these sectors would have allowed a wage rise, or that the price sensitivity of labour would have increased labour supply of home workers, in which case. EU-8 workers have filled jobs which would have otherwise gone unfilled, and therefore they have probably increased growth rates.

Arguments that immigration has caused problems of social integration and social cohesion are too complex to deal with in this paper, save to say that they have provoked a discussion of the merits of multiculturalism and diversity v. integration in several European Countries and that the British Government eventually established Commission for Integration and Cohesion (promised after the $9 / 11$ attack) which is due to report in June 2007.

\section{Effects of labour mobility on the EU-8}

Most discussion in Western Europe concerns the effect of migration from EU-8 on the EU-15. There is almost no discussion of the effect of these migration flows on the economies of the EU-8 themselves. Virtually all EU-8 were opposed to the introduction of the transitional measures and continue to call for the lifting of restrictions. However, this may be motivated by political outrage at been cast as ' 2 nd class EU members' rather than any rigorous assessment of the needs of their economy. What effect has this migration had on their economic development? And as the transitional arrangements are relaxed, will even more workers leave?

There are arguments both positive and negative about the effect of the exodus on EU-8 economies. On the positive side, it is argued that EU-8 workers will return home with greater language and business skills, and will start new businesses which will benefit the economy. They may return with savings which will allow them to buy homes and businesses. Also the fact that most EU-8 workers in the UK do not have dependents living with them does not mean that they are not supporting dependents back home and this may be a valuable source of income in an economy with poor welfare systems. And if the migrant workers would otherwise have been unemployed, then the impact on the economy is positive. Given the unemployment rate for young people in Poland, this may well be the case.

On the negative side, so many young workers have left that many businesses are now complaining about recruitment and retention problems. The workers who have left are the better educated, with language skills and work ethic, in short, the type of workers that the economy needs most. It is estimated that Latvia lost between 4 and $10 \%$ of its labour force in the $18 \mathrm{mths}$ since accession (Woolfson, 2006b). Poland has similarly lost a sizeable proportion of its young working population.

The impact of future migration patterns may be more important than current migration levels. Eurobarometer found that 5\% of EU-8 workers expressed an intention to move within the next five years, compared with only $3 \%$ from the EU-15, and these were predominantly young, single people with a high educational level. Indeed 9 per cent of all 18-24 year-olds, and 6 per cent of 25-34 year-olds expressed their intention to leave (Eurofound, 2006: Table 3). Particularly worrying is that $12 \%$ of all those still studying said they were planning to leave. Four EU-8 countries stand out as having a high proportion of their population planning to leave - Lithuania has the highest proportion planning to leave with over 8 percent, followed by Poland, Estonia and Latvia. Given the size of its population (40 million), if 7 per cent of Polish people are planning to move to another EU country, this represents a very substantial movement of population. But the likely effect on the economy of these countries is even worse when it is broken down by age and educational level. These four countries look set to lose almost 40 per cent of their 
workers under 35 and one third of all those with average or high educational level, and the situation scarcely looks much better for other EU-8 countries (see Table 10).

Migration could therefore be causing more labour shortage and bottlenecks at home than it is solving problems in the EU-15 countries. Labour mobility represents a 'beggar-thy-neighbour' approach to solving problems of demography and leads to a spiral of decline. Some support for the labour shortage argument can come from the fact that the EU-8 countries have themselves received immigration from even poorer countries - Czech Republic, Hungary and Slovenia from China, Vietnam and Ukraine.

\section{Conclusions}

The 2004 enlargement has changed the whole debate about labour mobility within the EU. For the first time in nearly 50 years, the EU has ceased to lament the failure of the 'fundamental right' to live and work in any member state because it has started to become a reality. But rather than rejoicing, the exercise of this right has become highly controversial, with a substantial gap between the European Commission and economic opinion on the one hand and popular opinion on the other. Political realities have overridden economics. With the GDP per head of less than $30 \%$ of the EU average and half that of Poland, the British Government has announced that it intends to introduce transitional measures when Bulgaria and Romania join on $1^{\text {st }}$ January 2007, and is restricting access to all but skilled workers. Given the experience of EU-8 migration this decision flies in the face of economic reality and ignores the fact that most of the demand for CEE workers is for unskilled jobs. However, even without these restrictions it is uncertain whether many Bulgaria and Romania workers would come to the UK, because they have smaller populations, fewer English speakers, and stronger links with southern Europe.

As other countries ease their restrictions, will EU-8 workers now choose to go elsewhere, or will the level of migration increase, with a consequential detriment to their economies?

It might have been expected that the imposition of transitional arrangements by all but three of the member states would have altered and delayed labour market adjustments, but rather surprisingly, the figures compiled by the European Commission demonstrate that the transitional arrangements had little effect. Economic forces are the main determinant of the level of immigration.
But what of the future? The European Commission have argued that 'Since enlargement unemployment rates dropp(ed) significantly in almost all (EU-8). This suggests that there is no reason to expect increased pressure to move outside EU-8 countries...' (EC 2006:10). However, given the remaining differences in living standards and the level of previous migration, it is not obvious that this is a likely outcome. And although the evidence to date suggests that most of these EU-8 workers are temporary, it is still early days and the eventual outcome is uncertain. How many of these young temporary visitors will marry locals and become permanent residents? Perhaps they will gain promotion and develop careers. If the EU8 workers become permanent and do not develop careers, then migration has resulted in a misallocation of resources with the relatively well educated EU8 workers taking unskilled jobs in EU-15. This is not the market equilibrium of a European labour market which the European Commission envisaged.

\section{References}

European Commission (2002) Free movement of workers - achieving the full benefits and potential, Communication from the Commission (Com (2002) 694 final).

INGHAM, Mike and INGHAM, Hilary (2004) Enlargement and the labour market:perception, theory and fact. Industrial Relation Journal European Annual Review, p. 500-517.

European Commission (2006) Report on the Functioning of the Transitional Arrangements set out in the 2003 Accession Treaty (period 1 May 2004 - 30 April 2006). Communication from the Commission (Com (2006) 48 final).

European Foundation for the Improvement of Living and Working Conditions (2006) Mobility in Europe - Analysis of the 2005 Eurobarometer survey on geographical and labour market mobility.

DONAGHEY, J. and TEAGUE, P. (2006) The Free Movement of Workers and Social Europe:Maintaining the European Ideal. Paper delivered to the British Universities Industrial Relations Association Conference in Sligo, July 2006.

GRAHL, J. and TEAGUE, P. (1992) Integration Theory and European Labour Markets? British Journal of Industrial Relations, Vol 30(4), p. 515-527.

MARSDEN, D. (1994) The Integration of European Labour Markets. In European integration and the European labour market, Social Europe, Supplement 1, p. 1-38.

DUSTMANN, C. et al (2003) The Impact of EU enlargement on migration flows. UK Home Office Report 25/03.

Migration Watch UK (2003) Unmanaged Migration. Briefing Paper 11.1, $19^{\text {th }}$ May 2003.

Great Britain (2006) A joint report by the Home Office, Department for Work and Pensions, HM Revenue and Customs and Department for Communities and Local Government. Accession Monitoring Report - May 2004-June 2006'. 
GILPIN, N. et al (2006) The Impact of free movement of labour from Central and Eastern Europe on the UK labour market. Working Paper 29, Department of Work and Pensions, UK.

DOBSON, J. R. and JONES, G. (1998) 'Ethnic Discrimination: Public Policy and the Latvian Labour Market. International Journal of Manpower, Vol 19 (1/2), p. 31-47.

DOBSON, J. R. (2001) Ethnic Discrimination in Latvia. In Camille O'Reilly (ed). Language, Ethnicity and the State: Regional and Minority Languages in Europe, Volume 2 Minority Languages in Eastern Europe post-1989, Basingstoke: Palgrave.

DOBSON, J (2006) The Impact of Enlargement on EU Labour Market Regulation: a review of the issues. Paper given to 'The Next Decade Challenges for Business' Conference held at RISEBA, Riga on 2nd-3rd February 2006.

WOOLFSON, C.; SOMMERS, J. (2006) Labour Mobility in Construction: European Implications of the Laval un Partneri Dispute with Swedish Labour. European Journal of Industrial Relations, Vol 12, No 1, p. 49-68.

HARDY, J. and CLARK, N. (2005) EU Enlargement, Workers and Migration: Implications for Trade Unions in the UK and Poland. Paper given to the Global Unions Research International Workshop "Trade Unions, Globalisation and Development - Strengthening Rights and Capabilities of Workers", Novo Hamborgo, Brazil, January.

WOOLFSON, C. (2006a) Labour Migration and Industrial Conflict in the Enlarged Europe: Post Communist Legacies and Perspectives. Paper given to the British Universities Industrial Relations Association Conference in Galway, Ireland on 30 June 2006.

WOOLFSON, C. (2006b) Globalisation, Labour Standards and Migration in the New Europe. The Arthur Priest Memorial Lecture given to Manchester Industrial Relations Society on 19 October 2006. 